\title{
Article \\ Levinas and Responsibility in the Face of Violence: A View from Lithuania
}

Jolanta Saldukaitytè

check for

updates

Citation: Saldukaitytè, Jolanta. 2022. Levinas and Responsibility in the Face of Violence: A View from Lithuania. Religions 13: 185. https:// doi.org/10.3390/rel13020185

Academic Editor: Terry Lovat

Received: 10 December 2021

Accepted: 13 February 2022

Published: 21 February 2022

Publisher's Note: MDPI stays neutral with regard to jurisdictional claims in published maps and institutional affiliations.

Copyright: (C) 2022 by the author. Licensee MDPI, Basel, Switzerland. This article is an open access article distributed under the terms and conditions of the Creative Commons Attribution (CC BY) license (https:// creativecommons.org/licenses/by/ $4.0 /)$.
Department for Continental Philosophy and Religious Studies, Institute of Philosophy, Vilnius University, 01513 Vilnius, Lithuania; jolanta.saldukaityte@fsf.vu.lt

\begin{abstract}
This paper is an exploration of the possibility of responsibility in the face of violence. Invoking choices made within the Holocaust experience, the paper shows how, from Levinas' perspective, morality and humanity are tested. First, violence interrupts a person's integrity and forces upon him/her choices he/she would otherwise not make. Second, war as the ultimate form of violence alleges the introduction of a "new morality" to justify its atrocities. Yet, this is belied because morality cannot be defined solely by ontology or epistemology and needs to account for vulnerability and passivity. Recognizing that moral responsibility is conjoined with vulnerability reveals it to be deeper than the logic promulgated by war. This is confirmed by an analysis of Cain's question, which shows that evil arises by ignoring the face of the other, by a secondary effort to displace the primacy of being for-the-other.
\end{abstract}

Keywords: responsibility; freedom; choice; Levinas; Holocaust; Lithuania; vulnerability; war

\section{Introduction}

The call for infinite responsibility for the other overflows from all of Emmanuel Levinas' ethical philosophy. Were we to claim that we have done everything we could possibly do, everything within our power, it would still not be sufficient in a Levinasian context. As long as there is even one suffering person or person in need (in Levinas' words "the orphan, the widow, the stranger"), I have done not enough.

Infinite responsibility not only structures the relation between the subject and the Other but also lies at the core of subjectivity itself. The demands of responsibility with no limits, bottomless and "insatiable", constrict and constrain the subject, now conceived as a "hostage to the other". No doubt, such a responsibility might be crushing for the individual; it is difficult, or even too difficult. From this arises the temptation to find excuses, to take a break, to run and hide (as did Jonah). Moreover, we must distinguish between the ethical and the political plane. The latter is where one strives for justice for all and introduces structures, organizations, and principles which distribute responsibilities and relieve, in their way, the overwhelming weight of personal responsibility from the subject's shoulders. However, at the ethical level the I, the subject, remains inescapably-and inadequately-the moral "Atlas of the world".

To be human is to be responsible. Humanity is an ethical, not an ontological, calling. Neither ontological Sorge, nor self-annihilating trembling before God, nor, alternatively, the desire to experience everything, makes a human human. Rather, humanity arises in responding to and for the Other even before being called, even when a call has not been grasped, reaffirmed, and contracted reflectively. Ethical responsibility does not offer an easygoing or lightweight being in the world; it does not guarantee that its circumstances and demands will be favorable or even convenient.

The present paper asks if and how a subject remains responsible when undergoing or experiencing violence, when he or she has their very freedom challenged. Can the experience of violence provide an excuse to be less responsible, to suspend or to postpone 
a responsible response? What is the meaning of Levinas' seemingly excessive claim: "I who am responsible for the persecution I undergo" (Levinas 1998a, p. 59)? These questions will be explored, taking into consideration some personal testimonies from the historical context of the Holocaust which occurred in Eastern Europe. How can you be "your brother's keeper" if you yourself need help and protection? Or perhaps we must look to such boundary situations to expose what is essential and what is accidental in responsibility, including the responsibilities which are so often taken for granted during "peaceful" bourgeois life?

\section{Context: Not Only Auschwitz}

Yitskhok Rudashevski, a fifteen-year-old Jewish boy, left a short note in his diary on 7 April 1943: "The worst can happen to us at any moment" (Rudaševskis 2018). It is not some exaggerated statement or hyperbole but a reflection of the events of the past two days when five thousand Jews from the Vilna Ghetto, Lithuania, were taken to the nearby forest of Paneriai and murdered, their bodies disposed of in a mass pit. Later that same year, on 23-24 September, the entire Vilna Ghetto was "liquidated": some people were sent to concentration camps and death camps, most of the others were murdered in Paneriai. Rudashevski did not survive. His diary was found in 1944 as one of the testimonies of life in the Ghetto. The poet Abraham Sutzkever, who later had this diary published, was another resident of the Ghetto. He managed to escape on 12 September. In his memoirs, he describes Paneriai: "The Germans fell in love with the site: on the right there was the road along which victims could be conveniently hauled, and on the left was the Vilna-Warsaw railway just a quarter of a kilometer away. From there the Germans laid rails leading to a large pit. Once the death factory had been prepared and the word Ponary resounded with horror throughout the population, the Germans published a map of the city that included no trace of Ponary. In Ponary's place there was simply a green spot with the word Forest written on it. It was as though Ponary did not exist" (Sutzkever 2017, p. 246). It was as though the Jews had had no existence whatsoever, had neither lived nor been murdered.

Others too have borne witness to the last days of Lithuanian Jewry. Grigorij Schur is one of them. In his diary, he describes not only life and death in the Vilna Ghetto but also the bloody first days of the Nazi occupation. The Nazis invaded Lithuania on 22 June 1941. Killing - murder-in the streets started right away. Schur writes, also of Vilnius: "From the morning of 24 June, a massacre began in the garden of the Franciscan Church on Trakai Street $\langle\ldots\rangle$ : executioners shot Jews and Soviet soldiers detained on the streets or given and brought by complainants. A young Jewish girl was first brought. It seems, she was going to work and didn't feel any danger. The girl was taken in front of a machine gun built in the garden and immediately shot" (Šuras 2020, p. 31). Levinas' family-his parents and brothers-lived in Kaunas at the time. To this day, it is not known definitively where and when his family was murdered. It is possible that they were murdered in front of their apartment in Kaunas, on Mickevičiaus Street, in those first bloody days of the Nazi invasion, but it is not certain (Pažeraite 2014).

One of the most important illustrations in the contemporary Lithuanian imaginary of these early spontaneous Nazi killings is the now infamous massacre in Lietūkis garage in Kaunas. There, about sixty Jews were dragged into a courtyard and tortured and murdered with crowbars, spades, and chains by local Lithuanians and Nazis on 27 June 1941 (Dieckmann and Sužiedelis 2006, pp. 120-26). Recently, this massacre was presented and addressed in the movie Isaak (2019), by Lithuanian director Jurgis Matulevičius. Its powerful and shocking first scene brings us close to the essence of the violence, brutal, cruel, primitive, and meaningful—or meaningless—as well as to the confusion and often the collapse of morality during the Holocaust. Auschwitz is, of course, the most prominent image-in Europe, now globally-of the Holocaust because of its unprecedented depth and magnitude of torture, violation, and mass murder and because of its sheer horror in human history. However, it is important not to forget that it, along with all the other death camps, was not how the Holocaust massacres started. In Lithuania, Latvia, Estonia, 
Ukraine, and some other countries in Eastern Europe, most of the native Jews were just killed in the streets, shot by Nazis or their collaborators, in the neighborhoods where they lived or worked or were rounded up and marched a few kilometers away to be shot and thrown into mass graves in nearby forests and open fields. French priest Patrick Desbois names these mass murders in Eastern Europe "Holocaust by bullet" (Desbois 2008). Such an expression no doubt lacks the symbolic power of "Auschwitz", but it is closer to the vicious, murderous truth.

Yale historian Timothy Snyder, in his book Black Earth: the Holocaust as History and Warning (Snyder 2015), as well as in the book Bloodlands: Europe Between Hitler and Stalin (Snyder 2010), specifically concentrates on Eastern Europe and makes clear that any Auschwitz metonymy is inapplicable here. Furthermore, Snyder underscores the danger and mistake of reducing the Holocaust to Auschwitz and the other death camps. The danger and error arise not only because by the time concentration camps were established the vast majority of Jews had already been killed, but also, and more profoundly, because "it seems to separate the mass murder of Jews from human choices and actions. Insofar as the Holocaust is limited to Auschwitz, it can be isolated from most of the nations it touched as well as from the landscapes it altered" (Snyder 2015, p. 209). He suggests that because of the powerful image of Auschwitz, the local killings have been more or less forgotten, as "Auschwitz calls to mind mechanized killing, or ruthless bureaucracy, or the march of modernity, or even the endpoint of enlightenment. This makes the murder of children, women, and men seem like an inhuman process in which forces larger than the human were entirely responsible. When the mass murder of Jews is limited to an exceptional place and treated as the result of impersonal procedures, then we need not confront the fact that people not very different from us murdered other people not very different from us at close quarters" (Snyder 2015, pp. 209-10). So, according to Snyder, the image of Auschwitz, meant to remind us of humanity's inhumanity, by an ironic displacement enables its forgetfulness, and lets us distance ourselves from what happened in our streets to our neighbors, and ofttimes by our neighbors. The question then is not only what or how did it happen, but what does 'what and how did it happen' mean for us and what does it reveal about humanity, including our own.

The Western philosophical tradition encourages the questioning of everything. Nevertheless, might not questioning evil in certain circumstances be evil itself? How does one raise philosophical questions about the Holocaust without losing its specificity, without reducing it into an instance of this or that? Emil Fackenheim, the prominent Hegel and Holocaust scholar, some time ago argued that "philosophers have all but ignored the Holocaust" (Fackenheim 1985, p. 505). No doubt, in some parts of Europe during the Cold War any questions about the Holocaust, as with the Gulag, were prohibited by political powers. Officially, the Holocaust "did not exist". The victims murdered within the geography of what became the Soviet bloc were identified as the "victims of fascism", "Soviet citizens", or the "peaceful population" (Vitkus 2017). In Eastern Europe, to discuss the specificity of the event was not possible and was professionally and personally dangerous. However, even in other parts of the world, in the so-called "free world", it was and still is hard to find a way to talk about it without distorting it beyond recognition. No doubt times have changed, and important books and articles have been published, but it still remains difficult and is a topic all too frequently avoided by thinkers. According to Fackenheim, one of the reasons for this avoidance is that philosophers pay more attention to universals, and "they have little use for particulars, and less for the unique" (Fackenheim 1985, p. 505). Another reason is the ever-present painful difficulty, the caesura, the chiasm, of confronting the "devastating negativity" of the Holocaust. The evil of the Holocaust is not a theoretical or hypothetical question but rather concerns the concrete death of millions of people, of human beings, of our fellow human beings, and not only their death, but also their torture, their degradation, the savagery of their treatment, and the horror of their murder. Let us not forget that one million Jewish children-babies, infants, toddlers-were murdered in the Holocaust. Elsewhere, Fackenheim writes that the "Holocaust was a world of evil—an 
Unwelt or antiworld - that was previously unthought and unthinkable. It ruptures philosophical thought" (Fackenheim 1989, p. 285). David Patterson calls it "the demolition of meaning" (Patterson 2018, p. 161). In the face of such an exorbitance, there were some who questioned the very possibility of continuing the Western tradition of poetry and art, and perhaps also philosophy. The difficulty of representing the Holocaust in verbal or visual form has been reflected in philosophy and literature, in theater and cinema, by Patterson, Richard Kearney, Claude Lanzmann, and too many others to name. The Holocaust eludes the rational mind with horrors that cannot be captured, explained, or understood. Nothing would be enough. Levinas here is even more radical: he rethinks the very meaning and possibility of morality, not the end of morality, as one might have expected, but a deeper more profound recognition of the status of morality! Was not the Holocaust not only a mass murder of a people but the repudiation of humanity? In other words, Levinas' concern is the very possibility of morality, during the Holocaust, to be sure, but even more he is asking that we rethink if and how morality is possible after the Holocaust, in view of such an extreme event. The Holocaust, if it is to mean anything, must mean rethinking morality in such a way that no Holocaust can happen again. Or, to say this in another way: if and how can morality sustain itself while experiencing violence, all the way to the most vicious violence, degradation, torture, murder, and mass murder?

\section{Disruption of Personal Integrity}

Levinas' magnum opus Totality and Infinity starts with the statement: "it is of the highest importance to know whether we are not duped by morality" (Levinas 2007, p. 21). There are several ways we can be duped by morality, but for Levinas, the ultimate state which shakes morality is the new situation created by war. War, for all its barbarisms, is here understood as an extreme form of violence: it not only disrupts the existing order and way of life but is violence toward the individual and his or her integrity and free will. In the article "Freedom and Command" (1953), written more than ten years before Totality and Infinity, Levinas had already determined that: "Violence applied to a free being is < . . > war" (Levinas 1987, p. 19). We see that the notion of "violence", or one might say also of "war", is thus very broadly conceived. Looked at from other more specific angles, the thematization and conceptualization of the Other, "a reduction of the other to the same", and the "suppression or possession of the other" (Levinas 2007, pp. 43, 46) are different forms of violence. In "Signature", Levinas adds that "the adaptation of the Other [l'Autre] to the scale of the Same in the totality is not attained without violence, War, or Bureaucracy - which alienate the Same itself" (Levinas 1990, p. 294). So, violence is a moral evil that can take many forms: it is not only murder but hatred, tyranny, racism, antisemitism, reductionism, and so on. Roger Burggraeve, in his article "Violence and the Vulnerable Face of the Other", distinguishes these different forms of violence in Levinas' philosophy, making the point that: "Murder manifests itself not so much as a fact taking place once and for all, but as a passion driven by a well-determined intentionality—namely, to destroy the other totally" (Burggraeve 1999, p. 38).

What is common to these different forms of violence is the denial of the other. Violencethe violence which morality must confront-is an attack on the independence of the other, as well as on the independence of the self, by an attempt to impose a supremacy, of power or even of truth, by means of power. Violence violates human singularity, whether we call that singularity "autonomy", "sovereignty", "freedom" or, more deeply because of the conditioning of such characterizations, as Levinas argues and shows, "moral responsibility". He underlines that "violence does not consist so much in injuring and annihilating persons as in interrupting their continuity, making them play roles in which they no longer recognize themselves, making them betray not only commitments but their own substance, making them carry out actions that will destroy every possibility for action" (Levinas 2007, p. 21). Levinas in no way belittles physical pains but points, rather, to a deeper significance. The point Levinas makes here is important for this essay as it stresses that violence towards the other is a violence against their free will, against their moral judgments, and in a word, 
against their integrity, which is inseparable from their moral being. Violence is the attempt to compromise what makes a human human, against the "humanity of the human". In the face of violence, pain, deprivation, terror, and fear for one's life, to hold onto moral principles, to remain responsible, and to provide for the other and for others becomes much more difficult or almost impossible.

Schur, in his diary on 25 September 1943, a couple days after the Jews were forced to leave the Vilna Ghetto and were gathered in the square, gives this description: "Many desperately tried to be among the 'lucky ones'. Some mothers, in order to save their children, put them in sacks and carried them tied on their backs, pretending to be some of their leftover items; others-albeit scary to say-on the contrary, threw their children and, saying they were childless, fled to the right" (Šuras 2020, p. 163). The Nazis were not only murdering people but dehumanizing them. Dehumanization means not only subjecting people to inhuman conditions-starvation, exposure, overcrowding, lack of sanitation, and the like-but putting them in situations in which their humanity and integrity are threatened. People put in inhuman-dehumanizing conditions are forced to make impossible choices.

In the diaries of the Jewish police in the Kovno Ghetto, as well in the diaries of the Vilna Ghetto inhabitants, we find testimonies of dehumanization which leave us speechless. We read that the Nazis informed the Kovno Ghetto police that twenty people had to be chosen to be killed by the Nazis (Schalkowsky and Kassow 2014, p. 34). The Jewish police, no doubt trying to help, chose from their fellow Jews twenty who were sick, disabled, or old so the younger and healthier could live. Of course, it is an impossible choice, one human life is equal to the others, the sick are not lesser beings than the healthy, the old are not inferior to the young. No greater degradation of the human spirit can be imagined; no so-called "utilitarian" calculus can ever justify such arbitrary and forced discriminations. However, we learn that these kinds of situations and choices were not exceptional. We find them in the accounts of the Ashmyany Ghetto in the diary by Zelig Kalmanonich (Kalmanonovich 2021, p. 139), as well as in Rudashevski's (Rudaševskis 2018, p. 118). "Utilitarian" calculation there was also used as a last resort to save, as they thought, more lives, but instead, such calculations, with their implicit assumption that some persons are more worthy to live than others, put at risk the integrity, the moral core, of the human subject as such. In his reading of Levinas, John Drabinski agrees: "war makes us play a role in which we no longer recognize ourselves. $<\ldots>$ making us 'play roles' is not preparation for war-but violence itself. Identity makes war possible, violence inevitable. We are lost to ourselves, and morality slips away. Playing roles in which we no longer recognize ourselves enacts epistemological and ontological violence, as we no longer know ourselves and others, and so are alien to the being of the self and the beings populating our world" (Drabinski 2011, p. 138). Such impossible choices are of the utmost seriousness and the most meaningless at the same time. Unlike the distances of reflection, of freedom and of responsibility, they alienate the human from itself. They are themselves monstrous. By putting people in these situations, the Nazis were not merely delegating the work of selection, but deliberately extending and worsening their victims' suffering, more deeply mocking and destroying their hopes and the moral integrity of their choices. In the end, all the morally tortured choices the Jewish police were forced to make did not make any real difference because-as the Nazis surely knew beforehand-nearly everyone in the ghetto was killed, including the Jewish police. However, such choices were of the utmost seriousness in the sense that they remained in some sense human choices and in some sense, however attenuated and twisted, represented a taking of responsibility for the other, which in that situation was the only thing left which still mattered.

These situations demonstrate, too, that human freedom is not such an unconditional value as some thinkers, such as Immanuel Kant, Johann Gottlieb Fichte, and Jean-Paul Sartre, among others, have argued. The autonomy of free will is for Kant a necessary condition of moral acts. For Sartre, responsibility, for all that is meaningful, derives from the absolute inviolability of human freedom, which distinctively defines human existence. 
We are not going to discuss these positions, but it is important to recall that the primacy of freedom has a long and honored pedigree in the philosophical tradition. Bucking this tide, Levinas does not believe that human freedom, including freedom of choice, has this primacy. For him, freedom is not heroic or absolute. He sees that "one could, by intimidation, by torture, break the absolute resistance of freedom, even in its freedom of thought, that an alien order no longer hits us in the face, that we could accept it as though it came from ourselves, show how derisible is our freedom" (Levinas 1987, p. 16). Individual freedom loses its autonomy and is subject to physical abuse; hunger, torture, money, temptations of love, or power enslave the soul, until it is no longer able to make its own choices. Levinas doubts the fundamentality of freedom, yes, but more profoundly, he calls it into question, as we will see later, because of its own potential violence towards the other, the violence of its spontaneity. Here, in the above citation, we see that he acknowledges its weakness, its inability to resist violence: it can be broken, it is not heroic. Morality built upon freedom, then, would have too fragile a basis.

Others who have experienced torture and violence confirm Levinas' thought. (Nor should we forget that Levinas spent WWII in a German prisoner-of-war camp, segregated with Jewish prisoners of war.) Polish writer and political dissident Gustaw HerlingGrudziński writes: "I became convinced that a man can be human only under human conditions, and I believe that it is fantastic nonsense to judge him by actions which he commits under inhuman conditions-as if water could be measured by fire, and earth by Hell" (Herling-Grudziński 1986), and, he continues, "There it has been proved that when the body has reached the limit of its endurance, one cannot, as was once believed, rely on strength of character and conscious recognition of spiritual values; that there is nothing, in fact, which man cannot be forced to do by hunger and pain. This 'new morality' is not a code of decent human behavior, for its standard is expediency in action towards men, and though today its fangs are sharp and dangerous, its tradition reaches back to the Spanish Inquisition on which it cut those teeth. We must not dismiss this fact lightly" (HerlingGrudziński 1986). As torture survivor Jean Améry similarly confirms: "The tortured person never ceases to be amazed that all those things one may, according to inclination, call his soul, or his mind, or his consciousness, or his identity, are destroyed when there is that cracking and splintering in the shoulder joints" (Améry 1980, p. 40). These and similar testimonies show how the social condition created by the Nazis exposed not only the difficulty of morality but the destruction of its alleged basis in freedom. Describing life in the Kovno Ghetto, Samuel Gringauz (a Holocaust survivor) indicates that the inhabitants there lived in extreme conditions of recurring danger to life, including the pressures of hunger, cold, disease, and the grind of forced labor. "Under such conditions of pressure, the mere fact of existence, of physical survival per se and the sole striving to live on, became the supreme value and hence the gage for all other values. All other values, including moral values, under such conditions, took on a relative character. Every conflict of values posed the dilemma of self-sacrifice, and only individual heroes in individual moments were capable of meeting this test" (Gringauz 1949, p. 5). As Gringauz indicates, "The basic negative change was the inversion of the scale of moral values. That which in normal times was simply the framework and conditions for moral values - the process of living, mere existence-became an end in itself and the supreme value, while those moral values which were formerly the ends of life took on a relative and subsidiary character" (Gringauz 1949 , p. 17). The crimes of the Nazis and their collaborators and supporters were not only murder and torture, but the establishment, the normalizing, of the situations, such as those described by Gringauz and others, which eliminated the very possibility of morality. It is a mockery of the ethical order: not only is good questioned, but so too the difference between good and evil, the very grounds of morality, of responsibility, of human decency, to say nothing of justice.

As Levinas underlines war as an extreme form of violence, it suspends morality, reorienting the ethical relationship of I and Other to translate it into a game of immoral forces. We may argue that any kind of violence is an attack on morality, but war, unlike 
peace, has the way how to justify and legitimize it. What is rightly taken to be murder in peacetime becomes "enemy destruction" during war. It is not a matter only of killing re-situated into a context of soldiers fighting soldiers in war, a context which retains its morality (for all but absolute pacifists) by the specific standards of "just war" theories. No, war as violence and violence as war mean killing, torturing, cheating, lying, and the like, actions ordinarily recognized for their immorality, now treated as natural, or normal, or more precisely, as moral. In this way, the commandment "Do not kill" loses its meaning, which is to say, its moral imperative. In a state of war, violence, destruction, and killing are not only ordered, they are justified. As Adrian Peperzak summarizes: "In a situation of war, harming others, killing, cheating, and lying become "natural" and "normal"; they are even seen as patriotic obligations. The validity of the moral norms is shaken and seems to be suspended" (Peperzak 1993, p. 126). War not only crushes the individual with its horror, with its bombs and bullets, but it also establishes universal principles that justify those atrocities. Political violence seems in this way to trump and destroy moral order. John K. Roth agrees: "No event did more than the Holocaust to show that humanity has been duped by morality" (Roth 2005, p. 115). He underlines that it established a new normality in appropriating ethical vocabulary, producing "ethical" reasoning against ethics, resulting in oxymorons such as "Nazi ethics" and "Nazi conscience". Claudia Koonz, for example, in her book The Nazi Conscience, shows that the Nazis often had a very strong understanding of right in their wrong: "they denied the existence of universal moral values and instead promoted moral maxims they saw as appropriate to their Aryan community" (Koonz 2003, p. 1). This twisted devaluation of ethical vocabulary might be seen in an attenuated form to be continued in the devaluation of values and the deconstruction of meaning imposed by today's postmodernism and deconstruction, where "intellectually" everything endlessly means something else and never itself. Roth, in fact, does claim that such apparently refined academic discourses "show how reasoning can produce lethal rivalries, which undercut confidence about the philosophical and religious foundations, as well as the actual content, of moral traditions that were at odds with Nazism" (Roth 2005, p. 115).

In Lithuania, the Jews lived for hundreds of years side by side with Lithuanians, Poles, and other ethnic communities. Although the relations were not especially close, each group retaining its community identity, and were mostly economical, it was not hostile either. The war and the Nazi military invasion and occupation changed all that. Mass killings were immediately initiated by the Nazis, but they would not have succeeded as much as they did without collaborative involvement by the local people. We often hear it said that the locals willingly participated because of longstanding traditions of anti-Semitism or, conversely, that the collaborators, a small minority, were mostly criminals or barbaric persons. However, more observant historians, including Snyder and Christoph Dieckmann (Dieckmann and Vanagaite 2021), have rejected this reading for several reasons. First of all, they take note of the fact, which is glaringly obvious when one considers it, that such a reading conforms perfectly with Nazi propaganda. One must be wary, then, insofar as to keep repeating this interpretation also means to continue the Nazi propaganda narrative, which is to say, to replicate their colonialist narrative of liberating Lithuania from its oppressors, the Jews. Snyder insists that it is impossible to understand the Holocaust without including the larger context of Germany's politics. The destruction and elimination of sovereign states (Poland, Ukraine, Latvia, Lithuania) was an essential element of the brutality of Germany's war and occupation of Eastern Europe, to which the Holocaust contributed. He suggests that the events in Eastern Europe were unique, which becomes evident when compared to the other parts of the Europe. The "blood lands", as Snyder calls the area divided up by the infamous Molotov-Ribbentrop Pact, suffered not only Nazi occupation, Nazi killings, and Nazi death camps but immediately before that the Soviet occupation, Soviet persecution, and Soviet exile of tens of thousands of natives to distant Siberian Gulag labor camps. Zygmunt Bauman argues that "to make the Holocaust possible, antisemitism of whatever kind had to be fused with certain factors of an entirely 
different character. Rather than look into the mysteries of individual psychology, we need to unravel social and political mechanisms capable of manufacturing such extra factors and examine their potentially explosive reaction with the traditions of inter-group antagonisms" (Bauman 2000b, p. 33). So, both Snyder and Dieckmann also underline the importance of keeping the historical and political context in mind: the disorganization of society, the collapse of political institutions, the arbitrariness of authority, and their like, which also contributed to mass killing. The disordered, dispossessed, and colonized societies were much more exposed to the new political and moral norms, despite how wrong and immoral they were and were taken to be just a few years earlier. War justifies not only the killing but the destruction of humanism, or morality itself. Social and political violence breeds more violence.

It is as if the face of the other was eliminated and replaced with stereotypes, caricatures, and numbers. Eichmann, Kearney observes, "was unable to imagine that the person beside him-that the person he was demonizing as a Jew, the person who he believed deserved to be killed in order to purify the German race-was actually someone just like him" (Kearney and Kirby 2012, p. 9). It is not the intellectual imposition of a desired symmetry but a recognition of the same human dignity and vulnerability in not treating another person as an object or thing among the objects and things of the world. Killing the other does not have to begin or end with a knife stab: it has already started by putting the other person into one or another category, the individuation of a genus or a species. Thus begins dehumanization. In a war, in the vortex of immoral forces and deadly powers, the other does not a have face. "The soldier does not murder another soldier; the subject is not a murderer, the victim is not murdered. The soldier kills. The soldier kills a category 'enemy,' having given himself up, in the concession to war, to the category of warrior. Frenchman. Israeli. German. Vietnamese. Palestinian. Revolutionary. Patriot" (Drabinski 2011, p. 138). In this way, we can continue: "Communist. Jew. Enemy. Disabled. Homosexual. Foreigner. Immigrant", and so on. This is to take not only life but the personal name, to snub out singularity, to eliminate the first-person distinctiveness of existence: your name, my name, not a number.

In war as an ultimate form of violence, Levinas also sees an ontological principle, an event of being, at work. It is an order without residue, in which nothing remains outside; hence, nothing can be better, or worse for that matter. There is no Other left here, and the identity of the Same, far from being preserved, is also destroyed. War, like the calculating, cold mind, like universal truth, is a matter of totality: it "absorbs the multiplicity of beings" (Levinas 2007, p. 222). Bearing in mind the polemical nature of Heraclitus's polemos and Martin Heidegger's being (or, if one prefers, his "question of being"), Levinas notes that the polemic character of being is asserted throughout the history of Western philosophy: "The visage of being that shows itself in war is fixed in the concept of totality, which dominates Western philosophy. Individuals are reduced to being bearers of forces that command them unbeknown to themselves" (Levinas 2007, p. 21). Levinas acknowledges the deepest meaning of this domination: "being reveals itself as war to philosophical thought, that war does not only affect it as the most patent fact, but as the very patency, or the truth, of the real" (Levinas 2007, p. 21). Hence, if war, polemics, the erasure of otherness, the oblivion regarding identity, is the fundamental principle of all being, if we are in a constant state of the possibility of war, if there is no alternative to ontology, to being (and non-being as its complement), it remains to accept that war is reality itself, and we are duped by morality. "There can be no sense in being except for sense that is not measured by being. Death renders senseless all care the Ego would like to have for its existence and destiny. An enterprise with no outcome and always ridiculous; nothing is more comical than the care for itself taken by being doomed to destruction, which is just as absurd as questioning, in view of action, the stars whose verdict cannot be appealed. Nothing is more comical and more tragic. It pertains to the same man to be tragic and comic" (Levinas 2005, p. 56). According to Levinas, out of the voice of being we can only speak of the illusion of morality and, in agreement with Friedrich Nietzsche, argue that morality is only a mask, a role, and 
sincerity is only a pretense, an epiphenomenon, an attempt to outsmart and gain even more power than Thrasymachus or Niccolò Machiavelli. We, the victors, are not duped by morality, but our victims are.

By asking whether ontology, the will to power, polemos, and the principle of war are really primary, at the same time Levinas asks whether an affirmative answer would not mean that ethics is contested and denied. Is it possible to talk seriously about the importance of morality if we are constantly preparing for war? Is morality established and maintained only to delay potential war opportunities? Is the question "What is good?" only to be understood through a relationship with war, or does it have meaning despite the threat or the state of the war? If morality only matters in safe, secure, and comfortable times, if we live an ethical life only if and when it is comfortable for us or only if and when it is easy, does it matter at all? Is morality meant to be some privilege, luxury, or accessory which we can have only sometimes, when circumstances are favorable to us, and which we can and must discard when the going gets rough?

\section{Autonomy of Morality}

By posing the question-if it is a question - and trying to understand whether we are or are not duped by morality, Levinas seeks to discover how morality still has a meaning. Does goodness matter if it can be extinguished by war? Is it extinguished by war? "Can we speak of morality after the failure of morality?" (Levinas 1988, p. 176). How is it still possible, how can it still have authority?

To have meaning, it must be beyond the logic and play of being, beyond the question of being, whether being be taken here as subject or object. He doubts that rationality is sufficient, which does not mean, obversely (or perversely), that rationality is dispensable for it. Nor is Levinas interpreting responsibility as a duty. The danger with deontological ethics lies in reducing morality to law, norms, and duties, which are by themselves insufficient (though again not irrelevant) to grasp the exigency of responsibility. Obedience to duties can turn into a suspension of morality, replacing "good and evil" with the "lawful and unlawful", as if ethics were so simple and external. Although in certain ways Levinas' ethics is very close to that of Kant, he does not rely upon a universal categorical imperative. Levinas calls for moral standing, "the pre-original responsibility for the other", which is not measured either by being or pure rationality. The possibility "to find a sense to the human without measuring it by ontology, without knowing and without wondering 'what about [qu'en est-il de] ... ,' outside mortality and immortality-this may well be the Copernican revolution" (Levinas 2005, p. 57). Responsibility for the other is not an abstract rule, a universalized maxim, but a concrete response of one to the Other, what in Totality and Infinity Levinas called the "face to face." Nor is it grounded in freedom and initiative. As has already been said, for Levinas freedom is not heroic. When experiencing violence, with the loss of freedom, is responsibility extinguished as well? Is a person excused from ethics if not free or not informed enough? Or, to express this differently, in violent situations does one somehow gain a right to be unjust toward the other and to take care of oneself no matter what? Or, conversely, is to be free to be free to not keep promises or to break commands or to be free to hurt others, such as, for instance, by passing on infectious diseases? Richard Cohen, in his aptly entitled article "Choosing and the Chosen: Levinas and Sartre", underlines that in Levinas "the problem with freedom is precisely its spontaneous and unjustified character. The problem with freedom, in other words, is not ontological, not tragic but moral. What is truly disturbing about the spontaneity of freedom is its capacity to do violence, to harm or even to kill others. Freedom unjustified is also the freedom to murder. The problem with freedom by itself, then, is not at all its failure to be freer, but rather its potential harm, its unworthiness" (Cohen 2010, p. 142). So, if freedom is reducible to choosing, to be free would just as well include choosing to be evil, choosing to be wrong, choosing to hurt the other. The unrestricted right to be free is a recipe to justify harming others: "Either this means that there is no reason for morality and hence it can be concluded that everyone should act like the Nazis, or the moral law maintains its authority. 
Here is freedom; this choice is the moment of freedom" (Levinas 1988, p. 176). So, even if freedom is not the source of good, it remains, when detached from the face to face, the source of evil.

To show the potential violent character of freedom as well as the peculiarity of the autonomy of morality, Levinas recalls the story of Abel and Cain, which is not only a story about the first murder (a crime of another order compared to anything which occurred in the Garden of Eden) but is also a story about human relationality. After having killed his brother Abel, Cain evades God's question by retorting with another question: "Am I my brother's keeper?" (Genesis 4:9). This is the question of one unaware of the other, one who tries to deny and to avoid the other by effacing him/her. Levinas understands here that evil starts by denying the proximity of the other, by denying responsibility for the other. As Bauman explains, for Levinas "from that angry Cain's question all immorality began" (Bauman 2000a, p. 5). It is obvious that Cain's question is all too real, that is to say, it is only real but not moral, not ethical. The denial it affirms ("I am not my brother's keeper") is ontological, pure negativity, absolute refusal. It "comes from someone who has not yet experienced human solidarity and who thinks (like many modern philosophers) that each exists for oneself and that everything is permitted" (Levinas 1990, p. 20). Modern subjectivity, as understood by modern philosophy, according to Levinas, is defined not only by its rationality but, even more profoundly, as a subject free, a subject remaining at a safe distance from the impositions of others, the social world, despite its much vaunted existential "being-in-the-world". Cain is the biblical paradigm of such an egoism, which remains withdrawn from its situation, withdrawn from others, remaining free above all, free from the other.

The difficulty, for philosophers, is that Cain is already responsible even before consciously contracting his responsibilities and obligations. Cain, by killing his brother, breaks one of the most fundamental, if not the most fundamental of all commandments, indeed, one of the Ten Commandments-Thou shall not kill. However, one might object, such is cleverness, such is one use for logic: the Ten Commandments were not yet given! Socratic tradition seems to say that one must know the good to do the good. Levinasian ethics is insistent, to the contrary, that one does the good before knowing it. Claire Katz highlights some of the paradoxes: "Cain has neither moral knowledge nor the capability of seeing the face. Yet, Levinas describes him as someone who violated the moral order; he nonetheless should have seen the face. Levinas' description of Cain exposes an individual who is both incapable of seeing the face of the other while nonetheless responsible for the other" (Katz 2010, p. 172).

In addition, is not Cain legitimized - for philosophers-insofar as he is asking for a reason why he should be responsible: "Am I my brother's keeper?" However, for Levinas by asking to be given reasons to be responsible the I has renounced its responsibility! To ask this question, to require an intermediary, as it were, between evil encountered and my responsibility to mitigate that evil, is already to succumb to evil-it is already violence. To murder is evil, but an even greater evil, or let us say an even deeper sense of murder, from Levinas' point of view, is Cain's refusal to respond to the other at all, his evasion, his escape from the entire domain of the ethical, which is the human domain. As Katz notes: "For Levinas, evil is not about the wanton destruction of life $<\ldots$. . For him the source of evil is rather the inability to be attuned to the other. This kind of evil, the capacity to be so detached from humanity that one cannot see one's own responsibility in the order of things is, one might say, the precondition of all other evil" (Katz 2005, p. 216).

Let us keep in mind that here we are not talking about this or that particular evil, where moral questions can and do arise, or about practical questions regarding who, what, where, when, and the like. Ethics is not a flight of fancy, but involves giving food, shelter, clothing, council, and the like. It is down to earth, concrete; indeed, nothing is more concrete. Rather, here, in our philosophical consideration, it is a matter of the very priority of responsibility. For Levinas, to be human is always already to be responsible for others, such is the very "humanity of the human." Thus, Levinas criticizes-ethically criticizes-the possibility 
for Cain to choose whether to be responsible for his brother or not. "To be dominated by the Good does not mean choosing the Good from a position of neutrality in the face of an axiological bipolarity. The concept of such bipolarity already refers to freedom, to the absolute of the present, and would mean the impossibility of going beneath the principle to the absolute of knowledge. However, to be dominated by the Good is precisely to exclude for oneself the very possibility of choice, of coexistence in the present. Here is the impossibility of choice is not the result of violence-fatalism or determinism-it is unimpugnable election by the Good that, for the elected, is always already accomplished" (Levinas 2003, p. 53).

It is not, then, that I choose the Good but Good chooses me before I even engage with possibilities of choice. For Levinas "This antecedence of responsibility to freedom would signify the Goodness of the Good" (Levinas 2008a, p. 122). He argues that you do not choose the Good from some neutral perspective, including one described in terms of freedom. For Levinas "the Good choose me first before I can be in a position to choose" (Levinas 2008a, p. 122). The naked face of the other appeals to me despite my choice, despite myself (malgre-soi). Such a responsibility then comes before freedom: "through a responsibility limited by the freedom of he "who is not his brother's keeper," portends the Evil of the absolute freedom to play. Whence comes the seduction of irresponsibility in the heart of submission to the Good, the probability of egoism in the subject responsible for his responsibility, that is to say the very birth of the Ego in obedient will" (Levinas 2003, p. 55). As Katz stresses, this includes freedom of choice as well: "What choice do we make in being responsible? It might seem heretical to ask such a question. The answer should be obvious. We are responsible because we are free. We typically believe that it is only in light of recognizing our freedom and our ability to make choices that we can even speak of responsibility. Levinas' answer differs from the received view of the Enlightenment. Our responsibility begins prior to our freedom" (Katz 2003, p. 98). For Levinas, "the enslaving character of responsibility" (Levinas 2003, p. 53) overflows any choice. Nor is this "slavery" properly speaking, but service, service to and for the other before oneself. After Kant, it might be not easy to accept this seemingly convoluted structure of responsibility as we are used to assuming that we are responsible because we are free-" "autonomous" rather than "heteronomous" - and are able to act freely only in accord with rational moral law. The Kantian rational subject appears in an intellectually cleared and empty space, while for Levinas the subject arises through a concrete encounter with the other, an encounter which occurs not only in a certain place but also at a certain time. The other is singular, as am I in such an encounter. Here, it is not the place to discuss the temporal structure of responsibility, but it is important to stress that for Levinas responsibility comes not after I encounter the other, or not until I encounter the other, but before, as there is no time without the other. Indeed, we must not forget that humans are born not posited, that temporality is generational not merely personal, that neither the ego nor being is the origin of all things. "The responsibility for the neighbor is before my freedom in an immemorial past that is unrepresentable and was never present, more "ancient" than any consciousness of ... I am committed, in responsibility for the other, according to the singular figure that a creature presents, responding to the fiat in Genesis, hearing the world before having been a world and in the world" (Levinas 1998b, p. 166).

In a radical break with philosophy's attachment to freedom, to free thought, to the freedom to ask any and all questions, Levinas' ethics does not leave unjudged the possibility to ask Cain's question. To ask this question means to open the possibility for violence, for the denial of the other, for not seeing the face. The first question is not "Why me?", because it is always already me-me for-the-other, me alleviating the other's suffering first. "The sober, Cain-like coldness consists in reflecting on responsibility from the standpoint of freedom or according to a contract. Yet responsibility for the other comes from what is prior to my freedom. It does not come from the time made up of presences, nor from presences sunken into the past and representable, the time of beginnings or assumptions. Responsibility does not let me constitute myself into an I think, as substantial as a stone or, 
like a heart of stone, into an in- and for-oneself. It goes to the point of substitution for the other, up to the condition-or the noncondition-of a hostage" (Levinas 1998b, p. 71). In other words, to be I is to be responsible, outside oneself, as it were, for the other.

By being, by existing, by one's spontaneity, or the world's, everyone is already potentially a murderer, potentially violent toward the other. So, Levinas questions one's very right to be: "Do I not kill by being?" (Levinas 2009, p. 120). Again, it is not a real question, or rather it is a question which exceeds being and non-being. It brings to bear an idea of being or existence different to those which the existentialists Albert Camus or Sartre have introduced. The question is not Hamlet's question, not Leibniz's question of Grund, not Heidegger's Seinsfrage, but an ethical one. What concerns Levinas is not the question of the meaning of being but "the meaning of meaning", "the question that is contranatural, against the very naturalness of nature: 'Is it just to be?' $<\ldots>$ The most repressed question, but older than that which seeks the meaning of being" (Levinas 2008b, p. 72). To exist means to take a place "under the sun". 'Taking a place' for Levinas is seen not as an "ontological privileging of 'the right to exist"” (Levinas and Kearney 1986, p. 24) but as an ethical situation. It raises ethical questions: "it is not only the question 'Is my life righteous?' but rather, 'Is it righteous to be?'” (Levinas 2001, p. 163). The very effort of living is questioned. To put your life, your daily needs before the other, is to elevate your own freedom above responsibility. So, Levinas' question is not that of conatus essendi, the "effort of being" or "perseverance in being", not the question what is the ground of my being or why there is something rather than nothing, but rather the more challenging issue of do I not displace the other, do I not eat the other's food, do I not kill just by being? "[I]s not my place in being, the $D a$ of my Dasein, already a usurpation, already a violence in respect of the other?" (Levinas 2001, p. 225). The possibility of violence toward the other lies at the very core of the act of existence. As Burggraeve underlines, "As conatus essendi, I am uneasy about my own conatus essendi; I realize that the evidence of my striving to exist is not at all evident, that I might not outlive my self-interest after all. In the exercise of my effort of existing it occurs to me that, left to itself, that effort is brutal, and leave everything behind it, in its own wake" (Burggraeve 1999, p. 33). Cain's evasion, as well as any kind of evasion from responsibility, is an evidence of violent conatus essendi.

So, morality is found neither through new definitions nor by new rules, but by turning back to the concreteness, the specificity, the immediacy beyond givenness, indeed, the mortality, the vulnerability of the other, the other's need for help. It comes not from knowing what is good or right, but out of a "pre-originary susceptiveness", a vulnerability to the vulnerability of the other. It is ethical exigency which arises from the concrete face to face which refuses and trumps violence, an awakening to the primacy of caring over violence and killing, the awakening of responsibility. It does not submit to the calculations of war or survival, it escapes the logic of being, it overrides and undergirds lawfulness. Beyond all such limits and constraints, however well-meaning or utilitarian, it is, in Cohen's expression, "out of control": "giving to and for the other and all others ultimately without reserve, without end" (Cohen 2016, p. 29). Or, in Levinas' words, it is goodness "otherwise than being," beyond the logic of being good otherwise. "The seizure by the good, the passivity of 'enduring the good,' is a more profound contraction than moving the lips in imitation of that contraction to articulate the yes. Here ethics makes its entry into the philosophical discourse-rigorously ontological at the start-as an extreme reversal of its possibilities" (Levinas 2003, p. 53). Not my being, not being itself, essence, but the other, the other comes first. Faithful to this exigency, Levinas shows that ethics, not ontology, is first philosophy. For him, it is not some theoretical equilibrium or equation but the move, or counter-movement, which reorients the philosophical thought and gives it another meaning. Meaning, as he sees it, is not only the event of being, even if the human throughout the history of philosophy was reduced to ontology (Levinas 2000, p. 58). Giving ethics its due weight in philosophical discourse, which on its own, in homage to "free thought", has usually prioritized activity, autonomy, and sovereignty, Levinas does not fear emphasizing its passive character. I am not free to choose the good. The good already has 
chosen me. I am always already obligated to the other person without contract, without having asked for such responsibilities. Responsible, I am hostage to the other.

For Levinas, responsibility is not defined by ontological necessity or epistemological deduction but remains nonoptional, incumbent, falling on my shoulders, me first of all, just because I am human, and as such "otherwise than being." My subjectivity, as my humanity, begins only by being a responsible being. Humans are not human by virtue of being rational animals, but by virtue of their moral responsibility. Being for Levinas, as we see, cannot justify itself by itself. It is not enough to persevere in being, to be being as it were. Being gains meaning in ascendance, in the ethics, "better than being." It is a radical and disturbing structure that shatters our very existence: to be for-the-other before oneself. Mortal being is not simply a self-consciousness which raises the question of being, but is to be connected to other people, to the world, via generosity and justice. Prior to the revelation of being is exposure to the other, stretched out in responsibility to and for the other. That the relation with the other starts not by choice but by being chosen is encapsulated in the concise biblical expression: "Here I am!" [me voici]. To say "here I am" means not "me, me", a cry in the dark, or a "me first", but the expression of one's readiness to help others. The alterity of other person pierces me from an insuperable nakedness and poverty, the other's mortal vulnerability, overcoming my self-interests, rising to a higher "dis-interestedness," as Levinas says. "Here I am"-At your service." I cannot turn away, I am already obligated; the connection between us has already been established. Nothing is closer to me, nothing is more in me, as it were, more exigent upon me, my me as put upon, than my responsibility for the other. "As unreplaceable for this responsibility, I cannot slip away from the face of the neighbor without avoidance, or without fault, or without complexes; here I am pledged to the other without any possibility of abdication" (Levinas 1998b, p. 71).

Terrible inhuman situations, the suffering of violence, do not suspend responsibility but reveal its difficulty. I am still responsible even if I am the one experiencing violence. I am responsible, even for the faults and misfortunes which did not start in my freedom or choices. Responsible for all and everything, I am responsible even for my persecution and persecutors: "it is still I who am responsible for the persecution I undergo" (Levinas 1998a, p. 59). We must not confuse the extremity and inescapability of such responsibility for its fulfillment, for the reverse is the case. To recognize that responsibility is always already required, prior to consent or contract, is also in the same breath to admit that it is always too late its obligations, that more is always demanded. "An ethical meaning of the relation to the other, answering, in the form of responsibility before the face of the invisible that requires me; answering to a demand that puts me in question and comes to me from $I$ know not where, not when, nor why. A responsibility for the other 'my likeness, my brother', who is, however, sufficiently different from me for me to continue to hear from within me the Cain-like refusal to be his keeper. Fraternity in the human, but already the condition-or in condition-of hostage obliged to answer for the freedom of the other, for that which, after all, 'does not concern me.' A responsibility that no experience, no appearance, no knowledge comes to found; a responsibility without guilt, but in which, before the face, I find myself exposed to an accusation that the alibi of my alterity cannot annul" (Levinas 2008b, p. 71).

Levinas is aware (and he has later been criticized by postmodern thinkers) for the difficulty of this overwhelming responsibility which gets under your skin or sticks to you like the shirt of Nessus. It is not by choice, even if "To be without a choice can seem to be violence only to an abusive or hasty and imprudent reflection, for it precedes the freedom non-freedom couple, but thereby sets up a vocation that goes beyond the limited and egoist fate of him who is only for-himself, and washes his hands of the faults and misfortunes that do not begin in his own freedom or in his present" (Levinas 2008a, p. 116). Furthermore, Levinas continues, "To be responsible over and beyond one's freedom is certainly not to remain a pure result of the world. To support the universe is a crushing charge, but a divine discomfort. It is better than the merits and faults and sanctions proportionate to the freedom of one's choices" (Levinas 2008a, p. 122). Each person's responsibility, as exigency, is not limited by capabilities or abilities, not excused by our limitations or those 
of the situation. The responsible person is guilty before the other, has never fulfilled all the incumbent obligations, certainly, but the responsible person is also without excuse. You cannot evade being responsible.

This difficulty and infinity (as you have never done enough) of responsibility also shows its deeper, more profound origin. Even if violence breaks the free will of the subject, even if it disrupts the integrity of the actions, even if evil prevails, the importance of ethics, of morality, remains. So, if we recall some of the testimonies which were invoked at the start of this paper regarding difficult choices people were forced to make during the Soviet and Nazi occupations of Eastern Europe, including the choices Jews were forced to make in the ghettos, we may find objective reasons to justify and to understand their being in a stalemate, their limited possibilities and limited choices. However, if with Levinas we try to understand that morality is still possible before and after making these choices, after the devastating evil of the Holocaust, we see that no excuses can justify the moral horrors of violence or that such excuses are not enough, that they are excuses and not reasons. Indeed, the reverse is true: if justification for violence and murder is claimed, then and precisely then have humans failed abjectly, because their morality too is lost. The ultimate act of responsibility for Levinas, "dying for the other" (Levinas 1998a, p. 173), signifies the priority of the other over me all the way, without reserve, turning my mortality into goodness devoted to protecting the mortality of the other.

In 2013, Yad Vashem in Jerusalem presented an exhibit entitled “I Am My Brother's Keeper" dedicated to those it had honored as "Righteous Among the Nations." During the Holocaust "to be your brother's keeper" became all too concrete, immediate, imperativeto save your neighbor, to hide the stranger, risking one's own life, and all too often risking the lives of one's family. Behind every name, there are difficult choices. However, such difficult choices kept others alive and with them the hope that morality still matters, bearing witness to a responsibility more weighty than freedom, more vigilant than knowledge, and greater than the crushing powers of war.

Funding: This article is a part of the project "Modernity and Holocaust in Lithuania: Philosophical Analysis of Moral Dilemmas" (Vilnius University, Lithuania). Research was funded by a grant (No. S-MOD-21-8.) from the Research Council of Lithuania.

Institutional Review Board Statement: Not applicable.

Informed Consent Statement: Not applicable.

Data Availability Statement: Not applicable.

Conflicts of Interest: The author declares no conflict of interest.

\section{References}

Améry, Jean. 1980. At the Mind's Limits: Contemplations by a Survivor on Auschwitz and its Realities. Bloomington: Indiana University Press.

Bauman, Zygmunt. 2000a. Am I My Brother's Keeper? European Journal of Social Work 3: 5-11. [CrossRef]

Bauman, Zygmunt. 2000b. Modernity and the Holocaust. Ithaca: Cornell University Press.

Burggraeve, Roger. 1999. Violence and the Vulnerable Face of the Other: The Vision of Emmanuel Levinas on Moral Evil and Our Responsibility. Journal of Social Philosophy 30: 29-45. [CrossRef]

Cohen, Richard A. 2010. Levinasian Meditations: Ethics, Philosophy, and Religion. Pittsburgh: Duquesne University Press.

Cohen, Richard A. 2016. Out of Control: Confrontations between Spinoza and Levinas. Ithaca: State University of New York Press.

Desbois, Patrick. 2008. The Holocaust by Bullets: A Priest's Journey to Uncover the Truth Behind the Murder of 1.5 Million Jews. New York: Palgrave Macmillan.

Dieckmann, Christoph, and Saulius Sužiedèlis. 2006. The Persecution and Mass Murder of Lithuanian Jews during Summer and Fall of 1941. Vilnius: Margi Raštai.

Dieckmann, Christoph, and Rūta Vanagaitè. 2021. How Did It Happen?: Understanding the Holocaust. Lanham: Rowman \& Littlefield Publishers.

Drabinski, John E. 2011. Levinas and the Postcolonial: Race, Nation, Other. Edinburgh: Edinburgh University Press.

Fackenheim, Emil L. 1985. The Holocaust and Philosophy. The Journal of Philosophy 82: 505-14. [CrossRef]

Fackenheim, Emil L. 1989. To Mend the World: Foundations of Post-Holocaust Thought. New York: Schocken Books. 
Gringauz, Samuel. 1949. The Ghetto as an Experiment of Jewish Social Organization (Three Years of Kovno Ghetto). Jewish Social Studies 11: 3-20.

Herling-Grudziński, Gustaw. 1986. A World Apart. New York: Arbor House.

Kalmanonovich, Zelig. 2021. Hope Is Stronger Than Life. Vilna Ghetto Diary. Translated by Lempert Olga. Vilnius: Vilna Gaon Museum of Jewish History.

Katz, Claire Elise. 2003. LEVINAS, Judaism, and the Feminine: The Silent Footsteps of Rebecca. Bloomington: Indiana University Press.

Katz, Claire Elise. 2005. Raising Cain: The Problem of Evil and the Question of Responsibility. CrossCurrents 55: 215-33.

Katz, Claire Elise. 2010. Education East of Eden: Levinas, the Psychopath, and the Paradox of Responsibility In Radicalizing Levinas. Edited by Atterton Peter and Matthew Calarco. Albany: State University of New York Press, pp. 171-83.

Kearney, Richard, and Joseph Morrill Kirby. 2012. Working Through the Trauma of Evil: An Interview With Richard Kearney. In The Other Journal: Evil. Edited by Andrew Shutes-David. Eugene: Cascade Books, pp. 7-14.

Koonz, Claudia. 2003. The Nazi Conscience. Cambridge: Belknap Press.

Levinas, Emmanuel, and Richard Kearney. 1986. Dialogue with Emmanuel Levinas. In Face to Face with Levinas. Edited by Richard A. Cohen. Albany, NY: SUNY Press, pp. 13-33.

Levinas, Emmanuel. 1987. Freedom and Command. In Collected Philosophical Papers. Edited by Alphonso Lingis. Dordrecht: Martinus Nijhoff Publishers, pp. 15-24.

Levinas, Emmanuel. 1988. The Paradox of Morality: An Interview with Emmanuel Levinas. In The Provocation of Levinas: Rethinking the Other. Edited by Robert Bernasconi and David Wood. London: Routledge, pp. 168-80.

Levinas, Emmanuel. 1990. Difficult Freedom: Essays on Judaism. Translated by Sean Hand. Baltimore: Johns Hopkins University Press.

Levinas, Emmanuel. 1998a. Entre Nous: On Thinking-of-the-Other. Translated by Michael B. Smith. New York: Columbia University Press.

Levinas, Emmanuel. 1998b. Of God who Comes to Mind. Translated by Bettina Bergo. Stanford: Stanford University Press.

Levinas, Emmanuel. 2000. God, Death, and Time. Translated by Bettina Bergo. Stanford: Stanford University Press.

Levinas, Emmanuel. 2001. Is it Righteous to Be?: Interviews with Emmanuel Levinas. Edited by Jill Robbins. Stanford: Stanford University Press.

Levinas, Emmanuel. 2003. Humanism of the Other. Translated by Nidra Poller. Urbana-Chicago: University of Illinois Press.

Levinas, Emmanuel. 2005. Time and the Other. Translated by Richard A. Cohen. Pittsburgh: Duquesne University Press.

Levinas, Emmanuel. 2007. Totality and Infinity: An Essay on Exteriority. Translated by Alphonso Lingis. Pittsburgh: Duquesne University Press.

Levinas, Emmanuel. 2008a. Otherwise than Being or Beyond Essence. Translated by Alphonso Lingis. Pittsburgh: Duquesne University Press.

Levinas, Emmanuel. 2008b. Outside the Subject. Translated by Michael B. Smith. London: Continuum.

Levinas, Emmanuel. 2009. Ethics and Infinity: Conversations with Philippe Nemo. Translated by Richard A. Cohen. Pittsburgh: Duquesne University Press.

Patterson, David. 2018. The Holocaust and the Nonrepresentable: Literary and Photographic Transcendence. Albany: SUNY Press.

Pažèraitè, Aušra. 2014. Paskutiniai Emmanuelio Levino tẻvų namai kaune ir tèvo verslo reikalai (pagal keletą naujai surastu dokumentu). Religija ir Kultūra 14-15: 144-58.

Peperzak, Adriaan Theodoor. 1993. To the Other: An Introduction to the Philosophy of Emmanuel Levinas. West Lafayette: Purdue University Press.

Roth, John K. 2005. Ethics During and After the Holocaust: In the Shadow of Birkenau. Basingstoke: Palgrave Macmillan.

Rudaševskis, Icchokas. 2018. Vilniaus Geto Dienoraštis. Translated by Mindaugas Kvietkauskas. Vilnius: Lietuvos Žydu (Litvaku) Bendruomenè.

Schalkowsky, Samuel, and Samuel D. Kassow. 2014. The Clandestine History of the Kovno Jewish Ghetto Police. Washington, DC and Bloomington: Indiana University Press in Association with the United States Holocaust Memorial Museum.

Snyder, Timothy. 2010. Bloodlands: Europe between Hitler and Stalin. New York: Basic Books.

Snyder, Timothy. 2015. Black Earth: The Holocaust as History and Warning. New York: Tim Duggan Books.

Sutzkever, Abraham. 2017. The Vilna Ghetto. In The Complete Black Book of Russian Jewry. Translated by Marina Shambadal, and Victoria Chernyak. Edited by Ilya Ehrenburg, Vasily Grossman and David Patterson. London and New York: Routledge.

Šuras, Grigorijus. 2020. Užrašai. Vilniaus Geto Kronika 1941-1944. Translated by Algimantas Antanavičius, and Nijolè Kvaraciejūtè. Vilnius: Inter SE.

Vitkus, Zigmas. 2017. Paneriu vaizdinio lūžiai J. Mackiewicziaus esè “Paneriai-bazè". Lithuanistica 63: 77-94. 